\title{
Influence of Enso to Variability of Rain Chain at Tropical Cyclon in Southern East Nusa Tenggara
}

\author{
Candra Febryanto Patandean \\ Meteorology, Climatology and Geophysics Agency IV Makassar \\ Email: chandrafebryanto@yahoo.com
}

(Received: July 1-2019; revised: October 10-2019; published: December 31-2019)

\begin{abstract}
The Region of East Nusa Tenggara province which is geographically situated around Equator is an area immediately adjacent to place where the growth of tropical cyclones. This research to determine the variability of tropical cyclones that have happened, how the influence of ENSO on the variability of tropical cyclones, and how the impact of tropical cyclones on rainfall in East Nusa Tenggara. In this study, the rainfall data used is represented by 8 stations observations in the region of NTT, namely Kupang, Rote, Sabu, Waingapu, Ruteng, Maumere, Larantuka, and Alor, with period of 19 years ie the assessment year 1996-2014. The data was obtained from Era Interim ECMWF. Tropical cyclone data was obtained from JTWC-Japan and TCWC-Australia, covering a maximum sustained wind data, position, and lifetime cyclone. Rainfall data obtained from Climatological Station of Lasiana-Kupang. Results of the analysis showed that during the study period the total incidence of tropical cyclones in the south of East Nusa Tenggara many as 113 cases, with an average of 6 events cyclones per year and were distributed mainly in the winter between November and April. The results also show that ENSO influence on tropical cyclone variability indirectly to the parameter of tropical cyclones.
\end{abstract}

Keywords: Tropical cyclone, ENSO, Precipitation, Atmospheric Dynamics.

\section{INTRODUCTION}

The mass of warm and humid air in the tropics is very easy to become labile resulting in the condensation process releasing latent heat energy excessively. This energy is then used as the main energy source in the formation of thunderstorms and other tropical disturbances, namely tropical cyclones (McGregor and Nieuwolt, 1998 - in (Larasati, 2013)). Even though it does not cross the Indonesian mainland, the influence of tropical cyclones that occur in the Indian Ocean remains felt in the weather on islands in Indonesia (Tjasyono, 1994 in (Dey, 2014)This is caused by a low-pressure weather system with a diameter of $500-800 \mathrm{~km}$ that is owned by tropical cyclones (Holland, 1997)

Tropical cyclones are a synoptic scale phenomenon characterized by a low pressure formed generally in the tropics that has a low latitude between $10^{\circ}$ and $20^{\circ} \mathrm{N} / \mathrm{LS}$ from the equator. For the Indonesian region tropical cyclones only appear at $10^{\circ}$ latitude from the equator. The southern territorial waters of Indonesia are directly adjacent to three cyclone basins namely the western North Pacific ocean basin, the northern Indian Ocean basin and the southern Indian Ocean basin. Tropical cyclone activity in these three basins will influence each other because of the tendency of cyclone activities that correlate between basins (Frank \& Young, 2007) so that the global weather phenomenon that occurs in these two basins will affect tropical cyclone variability in the waters of southern Indonesia. 
278|Jurnal Ilmiah Ilmu Administrasi Publik: Jurnal Pemikiran dan Penelitian Administrasi Publik

Volume 9 Number 2, July- December 2019. Page 277-286

The impacts of tropical cyclones in Indonesia include: Fransesca tropical cyclone which occurred at the end of January 2002 in the northwest of the island of Java with a life time of 15 days which greatly affected the amount of rainfall in the western part of Indonesia, especially Java and Sumatra. The great flood that occurred in Jakarta was allegedly the result of this cyclone. Other than that, at the same time Chris's tropical cyclone took place in northern Australia. The combination of these two cyclones is thought to be the cause of high rainfall on the island of Java to cause flooding in Pekalongan, Sampang and Situbondo (reports of events and effects of tropical cyclones in Indonesia were published by the National Institute of Aeronautics and Space (LAPAN, 2004). The Fiona tropical cyclone that occurred in February 2003 which moved southwest away from the equator in Australia's west coast waters resulted in strong winds and flooding in Indonesia's territory (Dupe, 2003)The Indigo tropical cyclone that (LAPAN, 2004) In the Ende and East Flores (NTT) districts, the Inigo cyclone caused flooding and landslides (Mustika, 2008 in (Novrinda, 2014)).

The Australian Bureau of Meteorology (BOM) recorded 189 occurrences of tropical cyclones in the Indian Ocean in 1979-1998. This tropical cyclone consists of tropical cyclones that occur $5 \mathrm{~km}$ to $3000 \mathrm{~km}$ from Indonesia. Based on the radius of influence and differences in the position of the tropical cyclone path, not all tropical cyclones affect the weather on islands in Indonesia. Likewise it is known that ENSO also plays an important role in tropical cyclone variability in ocean basins from the northern hemisphere, although the influence of environmental factors at the beginning of the occurrence and development of tropical cyclones varies for different basins (Kuleshov et al., 2009)

The East Nusa Tenggara Province which is geographically located south of the equator with astronomical location at $11^{\circ} 10^{\prime} \mathrm{LS}-07^{\circ} 30^{\prime} \mathrm{LS}$ and $118^{\circ} 30$ 'BT $-125^{\circ} 20^{\prime} \mathrm{BT}$, is an area directly adjacent to the place where tropical cyclone grows (basin), so that the impact must be watched out, both directly and indirectly from tropical cyclones that affect the weather, especially rainfall in the East Nusa Tenggara region.

ENSO is the most important ocean-atmosphere interaction phenomenon that influences inter-annual climate variability on a global scale. It has been proven that ENSO is a significant contributor to year-to-year tropical cyclone variability in most ocean basins, (Landsea, 2000), ENSO alters global atmospheric circulation that affects the frequency of tropical cyclones by changing the source of lower tropospheric vortices and vertical wind shear (Landsea, 2000) In response to each different basin to ENSO, some indicate changes in frequency of events, while others affect the displacement of the initial tropical cyclone location (Landsea, 2000). Tropical cyclone activity in the Pacific basin is directly affected by changes in sea surface temperature while for other basins it is only indirectly affected through teleconection (Landsea, 2000)

Therefore the authors are interested in examining the Effects of ENSO on the Variability of Rainfall in Tropical Cyclones in the Southern Waters Region of East Nusa Tenggara.

The formulation of the problem studied in this study is: what is the tropical cyclone variability in the waters south of NTT?, how does the tropical cyclone affect rainfall in NTT?, what is the contribution of cyclone-affected rainfall to the average monthly rainfall in NTT?, what is the influence of ENSO on tropical cyclone variability in the waters south of NTT?

The research objectives studied are: determine the variability of tropical cyclones in the waters south of NTT, analyze the influence of tropical cyclones on rainfall in the NTT region., 
identify the contribution of cyclone-affected rainfall to the average monthly rainfall in NTT, knowing the effect of ENSO on tropical cyclone variability in the waters south of NTT using marine and atmospheric parameters.

The benefits of the research studied are: making a general weather analysis or description of the existence of tropical cyclones which are very dangerous for the people in Indonesia, especially in the waters south of NTT, roviding extreme weather information to the public, and government agencies regarding the influence of tropical cyclones in the Southern Waters of NTT, poviding an understanding of the theory / concept to the people around the NTT region about tropical cyclones that occur in the waters south of NTT.

\section{METHOD}

This type of research is a type of descriptive research. Variable research that is used in tropical cyclones with the following parameters: tropical cyclone events for a year, the Nino Oceans Index (ONI) in several periods, monthly distribution of tropical cyclones in several periods, and monthly distribution of trajectory (distance) of tropical cyclones in several periods.

The data sources used in this study are as follows: tropical cyclone historical data for the period 1996 - 2014 for the southern region of East Nusa Tenggara, Indonesia, at $5^{\circ} \mathrm{LS}-20^{\circ}$ LS and $110^{\circ}$ East $-135^{\circ}$ East, downloaded from http://australiasevereweather.com/ Daily rainfall data from 1996 - 2014 for 8 points of BMKG Observation Station in East Nusa Tenggara province, with the position of the Station.

Data on months and years of ENSO events. ENSO events are determined based on the Oceanic Nino Index (ONI) downloaded from: https://www.cpc.ncep.noaa.gov/ . From the ONI data, it was known that during the period 1996 - 2014, El Nino events occurred in 1997, 2002, 2004, 2006 and 2007, while La Nina events occurred in 1996, 1998, 1999, 2000, 2007, 2010 and 2011. The rest are years with neutral ENSO conditions.

Daily (daily) reanalysis data from the ECMWF Interim Era at a resolution of $0.125^{\circ} \times 0,125^{\circ}$ from January 1996 to December 2014, which consists of wind data components u and $\mathrm{v}$ (to find vorticity values, divergences, vertical wind shear and to display wind flow patterns), Sea Surface Temperature, and relative humidity.

The data analysis method used is 1 . the method of trajectory (distance) of tropical cyclones to the maximum contribution of rainfall,then calculating the maximum and minimum distances at the beginning of formation, when reaching maximum intensity, and when the cyclone decays to the position of each station observation when contributing maximum rainfall. The distance of the storm center is calculated based on the position of the center of the storm at the maximum intensity of the position of the rain observation station by using the manual method by calculating the difference in latitude and longitude using the Pythagoras formula. This distance is calculated by the equation:

$$
R . \mid\left(x_{p b}-x_{s t a}\right)^{2}+\left(y_{p b}-y_{s t a}\right)^{2} \times 111 \mathrm{~km}
$$


280|Jurnal Ilmiah Ilmu Administrasi Publik: Jurnal Pemikiran dan Penelitian Administrasi Publik Volume 9 Number 2, July- December 2019. Page 277-286

By:

$\mathrm{R}=$ distance $(\mathrm{km})$;

$\mathrm{X}=$ station longitude (degree);

$\mathrm{Y}=$ station latitude position (degree); $\mathrm{pb}=$ storm center; $\mathrm{sta}=$ rain observation station

This composite method is used to averaged several patterns of a particular parameter so that one pattern is expected to represent several existing patterns. Composite analysis of parameters for tropical cyclone formation, namely: SST composite analysis, vertical wind shear, divergence, wind flow pattern, and $850 \mathrm{mb}$ layer vorticity, and relative humidity $(500 \mathrm{mb})$ in the period active cyclone (January) and inactive cyclone period (July).

The following is a research flow diagram which is a step to support the research process that will be made so that research can run more directed and systematic.

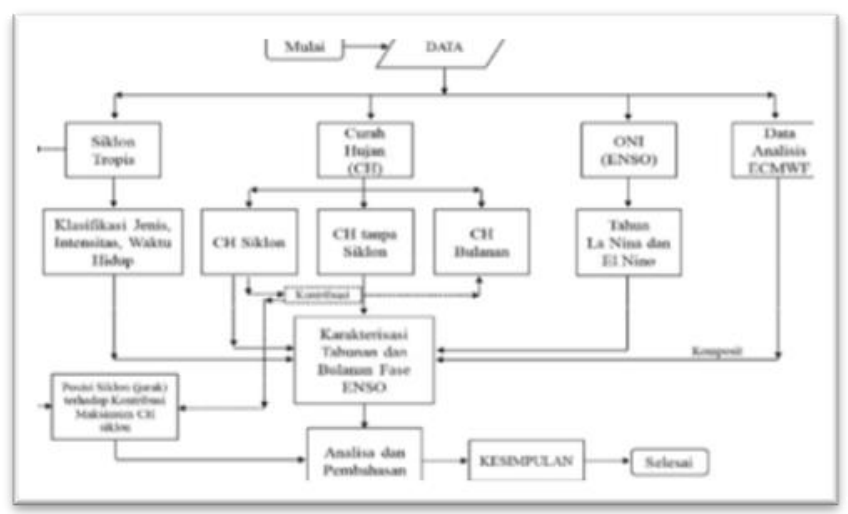

Figure 1. Flowchart of research

\section{RESULT AND DISCUSSION}

\section{Analysis of Annual Tropical Cyclones}

In this study, it was known that during the period 1996 to 2014 there were 113 cyclone incidents in the study area with an average incidence of 6 events per year. Of these amounts can be classified based on the annual and monthly distribution of the frequency, type, intensity and life time of tropical cyclones. The plot of the distribution of tropical cyclones in the study area can be seen in Figure 2. 


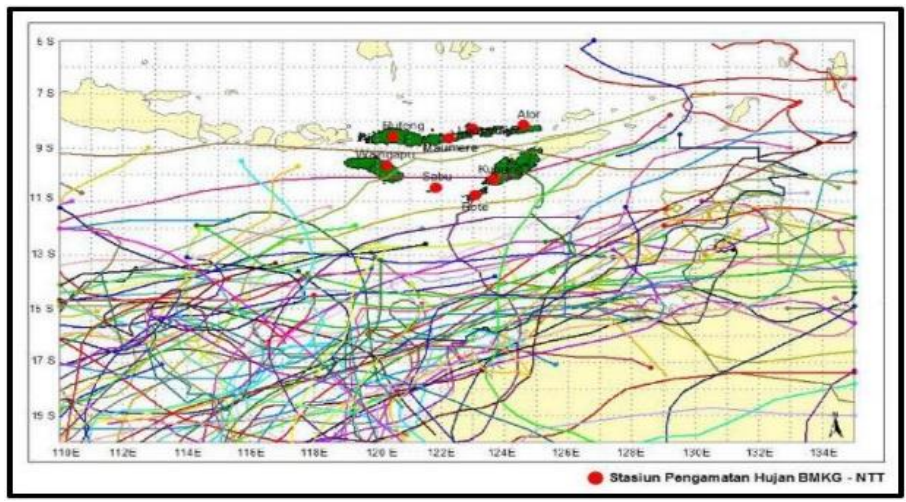

Figure 2. Tropical cyclone track distribution map in $1996-2014$

From figure 2, it appears that tropical cyclones occur in the study area not only from the beginning of the formation but also the place where the cyclone ends. When compared with the number of tropical cyclones for all BBS based on the 2014 Annual Report from JTWC, the number of cyclones between 1996 - 2014 was 504 events, so that the number of cyclones that occurred in the study area was $22.42 \%$ of the total cyclones on BBS for that time period. This shows that the southern region of Indonesia (especially NTT) is one of the most active tropical cyclone regions. The number of annual tropical cyclones in the period $1996-2014$ in the study area was distributed evenly between 1-9 events each year with the smallest number of cyclones, namely 1 event in 2014, and the highest as many as 9 events in 1996, 1999, 2000 and 2011. The distribution of tropical cyclone events every year can be seen in Figure 3.

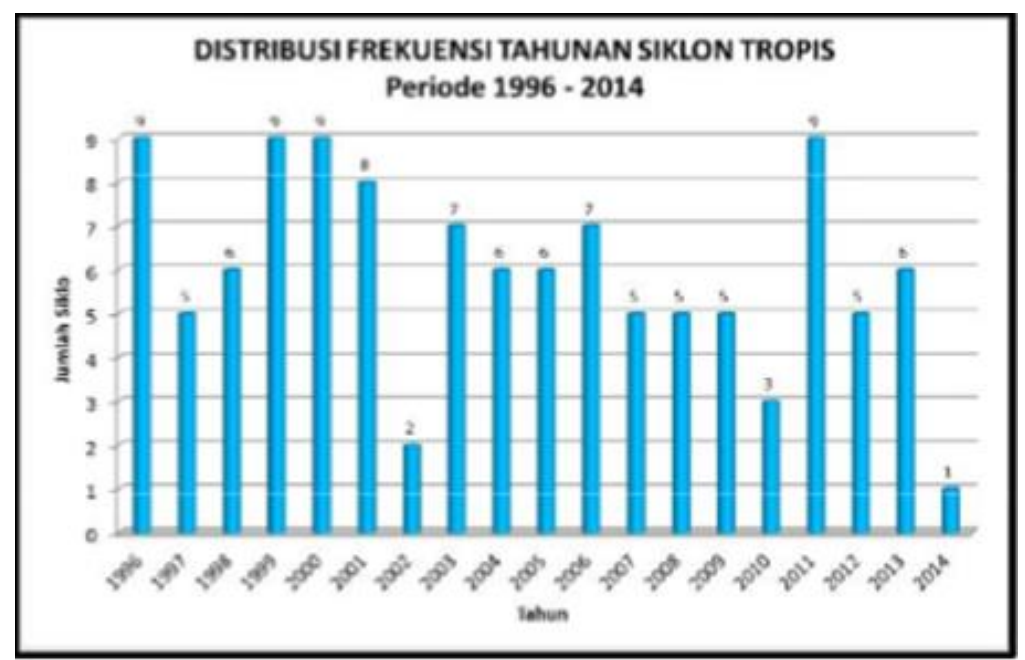

Figure 3. Annual tropical cyclone frequency distribution

From the results of data processing, it is known that the frequency distribution of tropical cyclones is strongly influenced by ENSO phenomena both in the El Nino, La Nina, and neutral 
282 Jurnal Ilmiah Ilmu Administrasi Publik: Jurnal Pemikiran dan Penelitian Administrasi Publik Volume 9 Number 2, July- December 2019. Page 277-286

phases. The spatial distribution of tropical cyclone frequencies in the ENSO phase can be seen in figure 4. (Map distribution of tropical cyclones during the ENSO phase in the attachment).

In the figure it is clear that the tropical cyclone that occurred in the ENSO phase was 75 events or about $2 / 3$ of the total number of tropical cyclones compared to the number of tropical cyclones that occurred in the neutral phase as many as 38 events or about $1 / 3$ of the total cyclone. Tropical cyclones that occur in the La Nina phase are the highest with 50 occurrences, while in the El Nino phase there are 25 cyclone events, and neutral with 38 cyclone events. Thus an initial conclusion can be drawn that the southern regions of Indonesia (especially NTT) are strongly influenced by the ENSO phenomenon. The type of cyclone that occurred in the study area reached 49 tropical storm conditions, reaching as many as 59 tropical cyclones, and which only reached tropical depression as many as 5 events. If seen from cyclone tracks, tropical depression can occur for a long time if the direction of movement is parallel to the equator, while tropical storm and tropical cyclone conditions generally begin at latitude $10^{\circ} \mathrm{LS}$, only around $14.2 \%$ (16 events) of the total overall events that occur below latitude $10^{\circ} \mathrm{LS}$.

\section{Analysis of Monthly Tropical Cyclones}

Monthly distribution for all periods from 1996 - 2014 peaked in January with the number of cyclones as many as 28 cyclones and the lowest in May as many as 1 cyclone, while in 4.2 Analysis of Monthly Tropical Cyclones June to October there is no cyclone (0 cyclone). In the ENSO phase, the number of significant cyclones occurred in the La Nina phase for all active cyclone periods, ie from November to April with a maximum of 12 cyclones in January and March, and the lowest 1 cyclone in November, while in May to October no cyclones occur $(0$ cyclones).

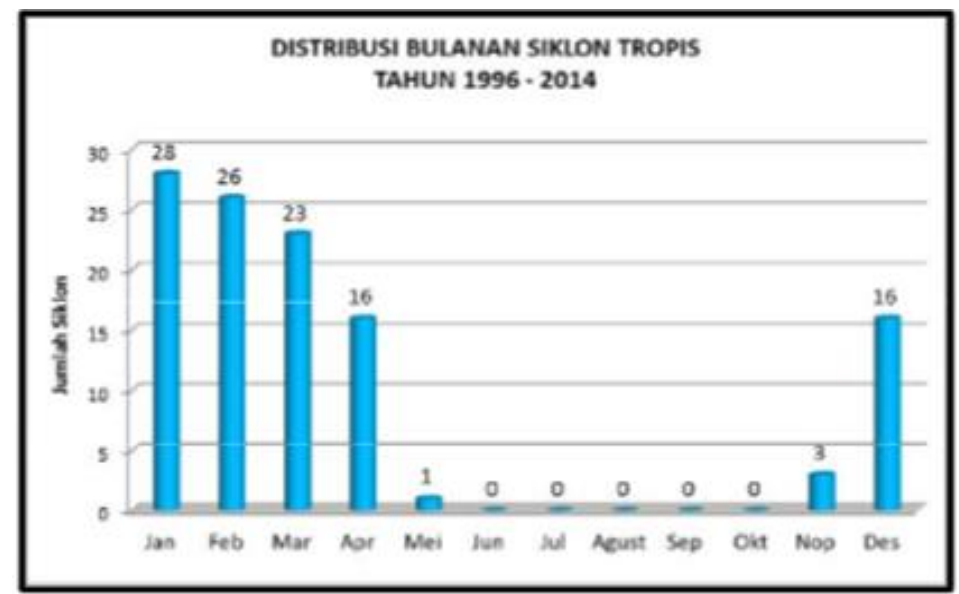

Figure 4. Distribution of the frequency of monthly tropical cyclones in the period 1996-2014 


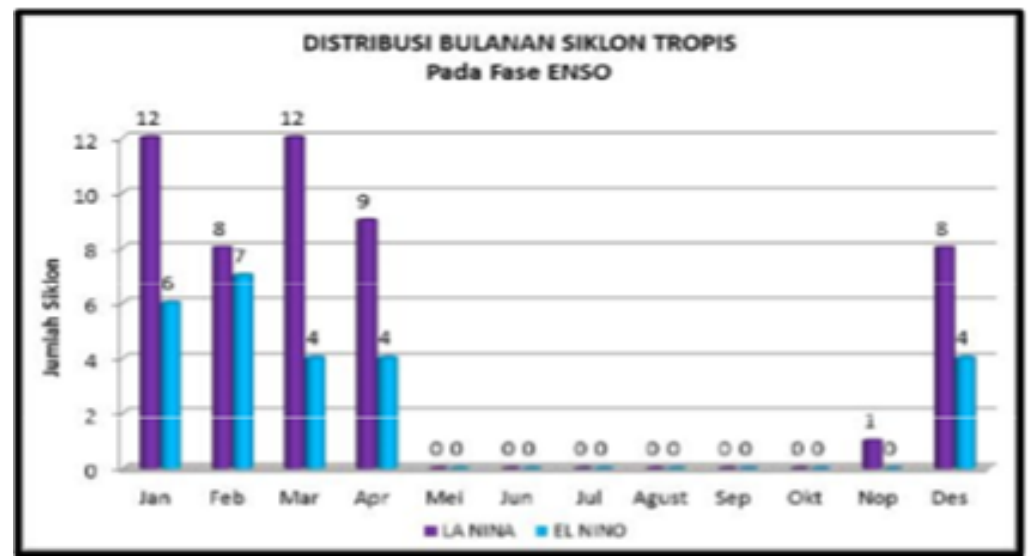

Figure 5. Monthly frequency distribution of tropical cyclone ENSO phase

\section{Impact of Tropical Cyclones on Rainfall in East Nusa Tenggara}

The most obvious tropical cyclone impact is on rainfall increase and reduction $(\mathrm{CH})$. The rainfall data used are daily $\mathrm{CH}$ data and monthly $\mathrm{CH}$ average data for the period 1996-2014 for each observation point. In this study, the initial study was carried out by separating rainfall data $(\mathrm{CH})$ when there was a cyclone, hereinafter referred to as $\mathrm{CH}$ cyclone, and there was no cyclone, hereinafter called $\mathrm{CH}$ without cyclones, in the study area $\left(5^{\circ} \mathrm{LS}-20^{\circ} \mathrm{LS}\right.$ and $110^{\circ} \mathrm{BT}-$ $135^{\circ} \mathrm{BT}$ ), then $\mathrm{CH}$ cyclones are compared with their monthly average rainfall to see the percentage of $\mathrm{CH}$ cyclone contributions to their monthly averages. The following is a graph of the monthly $\mathrm{CH}$ distribution at cyclone, without cyclones, and the monthly $\mathrm{CH}$ average for 8 observation station points:

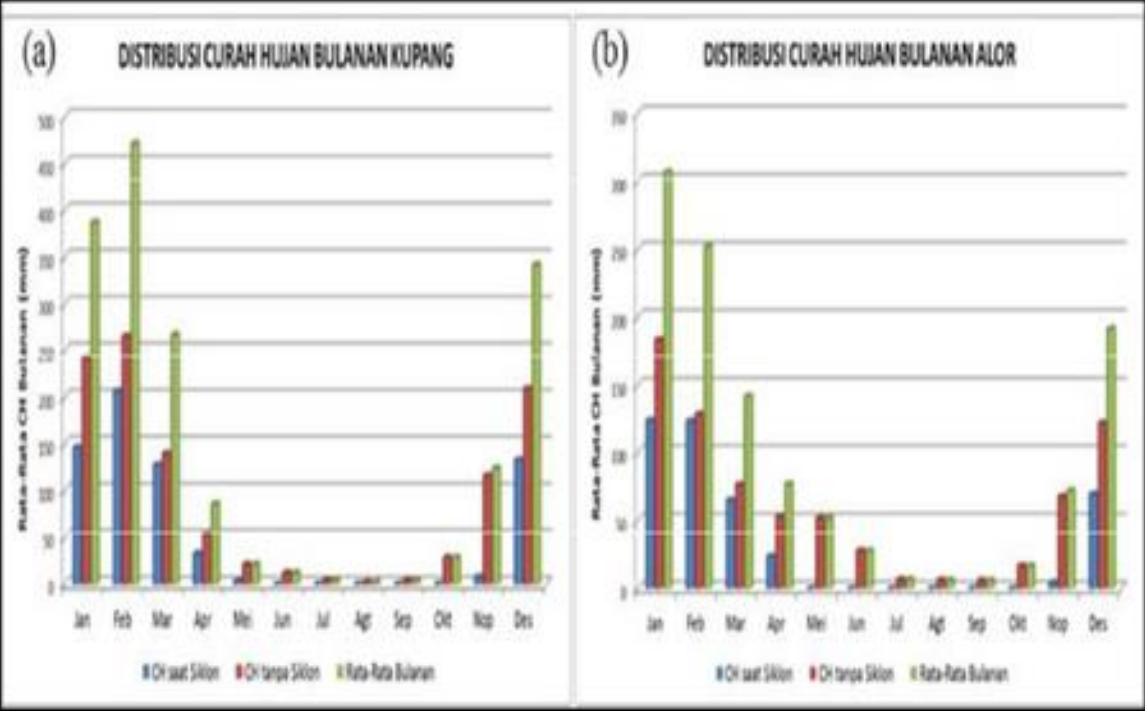


284 Jurnal Ilmiah Ilmu Administrasi Publik: Jurnal Pemikiran dan Penelitian Administrasi Publik Volume 9 Number 2, July- December 2019. Page 277-286

Figure 6. Distribution of cyclone $\mathrm{CH}$, without cyclone, and monthly average: (a) Kupang; (b) Alor

From the results of data processing it is known that throughout 1996-2014, the influence of tropical cyclones that occurred in the study area on rainfall for 8 rain observation points was relatively the same. In general, almost all areas of the $\mathrm{CH}$ observation cyclone are lower when compared to $\mathrm{CH}$ without cyclones, except on Sabu and Larantuka. On Sabu, $\mathrm{CH}$ cyclones were higher than $\mathrm{CH}$ without cyclones in April of $1.46 \mathrm{~mm}$, while in Larantuka, $\mathrm{CH}$ cyclones were higher than $\mathrm{CH}$ without cyclones in March and April which were $20.79 \mathrm{~mm}$ and $4.46 \mathrm{~mm}$. The dominance of $\mathrm{CH}$ without cyclones against $\mathrm{CH}$ cyclones is because throughout $1996-2014$ there were 3 cyclones that contributed $\mathrm{CH}$ in November. The highest contribution of $\mathrm{CH}$ cyclone to monthly $\mathrm{CH}$ occurs in Waingapu which is equal to $6.6 \%$ with the highest contributor of Alessia's tropical cyclone in 2013 at $71 \mathrm{~mm}$. The distance from the tropical cyclone at the beginning of its formation to extinction was $( \pm)$ 2487.04-3205.82 Km, whereas when it reached MSW (Maximum Sustained Wind) it was $\pm 2686.63 \mathrm{Km}$ from Waingapu. cyclone active period that occurs simultaneously the monsoon active period of Asia (rainy season) over the territory of Indonesia, including the East Nusa Tenggara region. $\mathrm{CH}$ 's cyclone contribution to the average monthly throughout 1996-2014 for 8 stations (points) observations ranged from $2.7-56.3 \%$. The lowest contribution $(2.7 \%)$ occurred on Sabu in November with the highest contributors from Alessia's tropical cyclone in 2013, and the highest occurred in Larantuka (56.3\%) in March with the highest contributor of tropical cyclones Jacob and George in 2007. In general the average contribution of $\mathrm{CH}$ cyclones to the monthly average in each observation point in the active cyclone period occurred in March at $46.6 \%$, while the smallest contribution in November was $4.5 \%$.

The highest contribution of $\mathrm{CH}$ cyclone to $\mathrm{CH}$ monthly occurred in Kupang, which amounted to $40.1 \%$ with the highest contributor of tropical cyclone Ophelia and Nicholas in 1996 amounting to $831 \mathrm{~mm}$. The distance from the two tropical cyclones at the beginning of their formation to extinction are respectively $( \pm)$ 1584.30 - 1691.44 Km (Ophelia) and 613.55 $1186.92 \mathrm{Km}$ (Nicholas), whereas when both tropical cyclones reach MSW each of them is \pm 1480.55 and $502.87 \mathrm{Km}$ from Kupang. In January, there were 28 cyclones contributing $\mathrm{CH}$ this month.

The highest contribution of $\mathrm{CH}$ cyclone to $\mathrm{CH}$ monthly occurred in Waingapu which was $42.8 \%$ with the highest contributor of Vince tropical cyclone in 2011 amounting to $101 \mathrm{~mm}$. The distance from the tropical cyclone at the beginning of its formation to extinction is $( \pm)$ $1176.21-1184.56 \mathrm{Km}$, while at the moment reaching MSW is $\pm 1510.62 \mathrm{Km}$ from Waingapu. Furthermore, in February, there were 26 cyclones contributing $\mathrm{CH}$ this month.

The highest contribution of $\mathrm{CH}$ cyclone to $\mathrm{CH}$ monthly occurs in Alor, which is equal to $49.0 \%$ with the highest contributor of Fiona tropical cyclone in 2003 of $223 \mathrm{~mm}$. The distance from the tropical cyclone at the beginning of its formation to extinction was $( \pm) 1104.86-$ $3899.61 \mathrm{Km}$, while when it reached MSW it was $\pm 2982.60 \mathrm{Km}$ from Alor. In March, there were 22 cyclones which contributed $\mathrm{CH}$ this month.

The highest contribution of $\mathrm{CH}$ cyclone to monthly $\mathrm{CH}$ occurred in Larantuka, which amounted to 56.3\% with the highest contributor of tropical cyclone Jacob and George in 2007 amounting to $330 \mathrm{~mm}$. The distance from the two tropical cyclones at the beginning of their 
Candra Febryanto Patandean.; Influence of Enso to Variability of Rain Chain... | 285

formation to extinction were respectively $( \pm) 834.20$ - $1714.03 \mathrm{Km}$ (Jacob) and 1345.29 $1719.30 \mathrm{Km}$ (George), whereas when the two tropical cyclones reached MSW each each is as far as \pm 1664.22 and $1364.71 \mathrm{Km}$ from Larantuka. In April, there were 17 cyclones contributing $\mathrm{CH}$ this month.

The highest contribution of $\mathrm{CH}$ cyclone to monthly $\mathrm{CH}$ occurred in Larantuka which was $52.8 \%$ with the highest contributor of Inigo tropical cyclone in 2003 amounting to $258 \mathrm{~mm}$. The distance from the tropical cyclone at the beginning of its formation to extinction was $( \pm) 855.37$ - $1761.48 \mathrm{Km}$, while when it reached MSW it was $\pm 932.35 \mathrm{Km}$ from Larantuka.

\section{CONCLUSION}

From the results of the processing of cyclone data, rainfall and cyclone formation factor analysis, some conclusions were obtained: during the research period (in 1996-2014) there were 113 cyclones in the study area with an average incidence of 6 events per year. The number of annual tropical cyclones is distributed almost evenly between $1-9$ events each year with the smallest number of cyclones, namely 1 event in 2014, and the highest as many as 9 events in 1996, 1999, 2000 and 2011. The effect of tropical cyclones that occur in the study area on rainfall for 8 rain observation points is relatively the same. In general, almost all areas of the $\mathrm{CH}$ observation cyclone are lower when compared to $\mathrm{CH}$ without cyclones, except on Sabu and Larantuka. On Sabu, CH cyclones were higher than $\mathrm{CH}$ without cyclones in April of $1.46 \mathrm{~mm}$, while in Larantuka, $\mathrm{CH}$ cyclones were higher than $\mathrm{CH}$ without cyclones in March and April, which were $20.79 \mathrm{~mm}$ and 4.46 respectively. $\mathrm{mm}$. Contribution of $\mathrm{CH}$ cyclones to monthly averages throughout 1996-2014 for 8 stations (points) of observations ranged from $2.7-56.3 \%$. The lowest contribution (2.7\%) occurred in Sabu in November and the highest occurred in Larantuka (56.3\%) in March. ENSO has an indirect effect on tropical cyclone variability by changing SST, vertical wind shear (VWS), wind flow patterns and vortices at $850 \mathrm{mb}$, as well as relative humidity in the mid-troposphere $(500 \mathrm{mb})$ in tropical cyclone formation, although not significantly.

\section{REFERENCES}

Dey, D. (2014). Analysis of the Impact of 2012 Tropical Cyclones on Weather Conditions in the East Nusa Tenggara Region,. Thesis Meteorology Study Program, STMKG, South Tangerang.

Dupe, Z. L. (2003). Tropical Storm and Extreme Weather, in Indonesia,.

Frank, W. M., \& Young, G. S. (2007). The interannual variability of tropical cyclones. Monthly Weather Review. https://doi.org/10.1175/MWR3435.1

Holland, G. J. (1997). The maximum potential intensity of tropical cyclones. Journal of the Atmospheric Sciences. https://doi.org/10.1175/15200469(1997)054<2519:TMPIOT>2.0.CO;2

Kuleshov, Y., Ming, F. C., Qi, L., Chouaibou, I., Hoareau, C., \& Roux, F. (2009). Tropical cyclone genesis in the Southern Hemisphere and its relationship with the ENSO. Annales 
286|Jurnal Ilmiah Ilmu Administrasi Publik: Jurnal Pemikiran dan Penelitian Administrasi Publik Volume 9 Number 2, July- December 2019. Page 277-286

Geophysicae. https://doi.org/10.5194/angeo-27-2523-2009

Landsea, C. W. (2000). El Nino Southern Oscillation and the Seasonal Predictability. Diambil dari www.aoml.noaa.gov/hrd/Landsea/ el_nino/ index.html

LAPAN. (2004). Report on Events and Effects of Tropical Cyclones in Indonesia. Diambil dari www.Lapanrs.com/result/php

Larasati. (2013). Contributions of Rainfall Affected by Tropical Cyclones on Monthly, Seasonal, and Annual Rainfall in Southern Indonesia in 1979-1998. Yogyakarta: , Faculty of Geography, UGM.

Novrinda. (2014). Study of the Effects of Tropical Cyclones on the Western Pacific Ocean on Rainfall in the East Kalimantan Region (Case Study of Chancu Tropical Cyclone, 11 and 16 May 2006). Thesis, Meteorology Study Program, STMKG,. 